\title{
HEAT PRODUCTION OF MAMMALIAN CELLS AT DIFFERENT CELL-CYCLE PHASES
}

\author{
C. Loesberg, ${ }^{1}$ J. C. VAN Miltenburg ${ }^{2}$ and R. VAN WuK ${ }^{1}$ \\ ${ }^{1}$ Department of Molecular Cell Biology and \\ ${ }^{2}$ Laboratory of General Chemistry, State University of Utrecht, \\ Padualaan 8, $3584 \mathrm{CH}$ Utrecht. The Netherlands
}

\begin{abstract}
Heat production of Reuber H35 rat hepatoma cells and murine $\mathrm{C} 1300$ neuroblastoma cells at different stages of the cell cycle were measured microcalorimetrically.

2. Reuber H35 monolayer cultures of Gl-phase cells and cells in S-phase were trypsinized, reincubated in suspension culture and immediately used for microcalorimetric measurements. There was a remarkable difference in the heat evolution of $\mathrm{H} 35$-cells in suspension derived from a monolayer culture of G1-phase cells and that of cells in S-phase of the cell cycle. Heat production of G1-cells was relatively continuous during the experiment. in contrast to S-phase cells that showed a decrease in heat production after an initial maximum.

3. Neuroblastoma cells synchronized by mitotic shake-off and cultured in suspension progressed through their cell cycle. They showed maximal heat production shortly before and during mitosis.
\end{abstract}

\section{INTRODUCTION}

ALL LIVING CELLS produce heat. The produced thermal effect is dependent on the cell type used and on the culture conditions. In general, the heat production of cells is a reflection of the activity and the viability of the cells (Kemp, 1980; Spink, 1980). Only very few data are known about in-vitro heat production of cultured mammalian cells (Schaarschmidt \& Reichert, 1981). For Reuber H35 hepatoma cells in suspension culture we demonstrated a mean heat production of $15 \mathrm{pW} /$ cell at $37^{\circ} \mathrm{C}$ (Loesberg et al., 1982). Data about the cell-cycle dependence of cellular heat production have never been published. The data presented here approach this question. In this study we used two cell lines which differ in their substratum-dependency for growth. The rat hepatoma cell-line Reuber H35 requires attachment to a plastic or glass substratum for proliferation. In order to study its heat production at different cell-cycle phases Reuber H35 cells in monolayer culture were accumulated in a G1-state by serum deprivation. Addition of serum to such Gl-cultures stimulates DNA synthesis and cell division (van Wijk et al., 1979a). At various stages during their progress through the cell cycle, cell suspensions were prepared and the heat production was determined microcalorimetrically.

Cells of the murine $\mathrm{C} 1300$ neuroblastoma cell line, clone Neuro-2A, are able to progress through their cell cycle during incubation in suspension in serumcontaining medium. The heat production of this cell line was determined continuously during incubation of a synchronized cell population in suspension in the microcalorimeter. Synchronization of the latter population was performed by accumulating cells in metaphase with Nocodazole, an antitumural agent which interferes with the formation of microtubules (de Brabander et al., 1976). The rounded and looselyattached mitotic cells were obtained by mechanical shaking of the monolayer (Terasima \& Tolmach, 1963). The data obtained from both cell types lead to the opinion that the major changes in the thermogenesis curves occurred after completion of the process of DNA synthesis.

\section{MATERIALS AND METHODS}

\section{Culturing of Reuber $H 35$ cells}

Reuber H35 hepatoma cells (Schamhart et al., 1979) were grown as monolayers on $165 \mathrm{~cm}^{2}$ tissue-culture Petri dishes (Falcon plastics, Los Angeles) at $37^{\circ} \mathrm{C}$. The culture medium was Eagle's basal medium enriched 4-fold with vitamins and amino acids, except for glutamin. The medium was buffered with tricine at pH 7.4. Foetal and newborn calf serum was added to a final concentration of 5 and $10 \%$, respectively. Cells were synchronized by incubation in a serum-free medium for 3 days (van Wijk et al., 1979a). Growth was reinitiated by addition of fresh serum-containing medium. At various times after serum readdition 6 Petri dishes with Reuber H35 cells (density 2 at 300,000 cells $/ \mathrm{cm}^{2}$ ) were washed twice with buffered saline and then trypsinized $(0.05 \%$ trypsin, $0.02 \%$ EDTA) for $5 \mathrm{~min}$ at room temperature. Then, ice-cold growth medium was added and the cells were collected, centrifuged at $300 \mathrm{~g}$ for $4 \mathrm{~min}$, washed with, and resuspended in, $2.5 \mathrm{ml}$ of ice-cold fresh medium. The temperature of the suspension was raised to $37^{\circ} \mathrm{C}$ immediately before $2.0 \mathrm{ml}$ of the suspension was used in the calorimeter. Determination of the heat production of the hepatoma cells was started by addition of the cell suspension through an inlet into the temperature-equilibrated $(100 \mathrm{ml})$ medium.

\section{Culturing of Neuro-2A cells}

Murine C1300 neuroblastoma cells, clone Neuro2A, were grown in Dulbecco's modified Eagle's medium (DMEM) without bicarbonate, but with $25 \mathrm{mM} N$-2-hydroxyethylpeperazine- $N-2$ ethane sulphonic acid (HEPES) buffer pH 7.6 supplemented with $10 \%$ foetal calf serum. The procedure of cell synchronization consisted of selective detachment of 
cells accumulated in mitosis by Nocodazole. The protocol in this procedure was that exponentially-growing monolayer cultures were grown for $24 \mathrm{~h}$, then shaken to remove loosely-attached and dead cells, and subsequently incubated for $7 \mathrm{~h}$ with Nocodazole at the final concentration of $0.15 \mu \mathrm{g} \mathrm{ml}^{-1}$. Mitotic cells were isolated by shaking and collected by centrifugation for $4 \mathrm{~min}$ at $200 \mathrm{~g}$, washed with and resuspended in $2.5 \mathrm{ml}$ of ice-cold fresh DMEM.

Further treatment for the measurement of heat production was as described for Reuber $\mathrm{H} 35$ cells. The number of mitotic cells per experiment was $3 \times 10^{7}$. These cells divided into approx. $6 \times 10^{7}$ cells at the time they were introduced in the incubation medium of the microcalorimeter.

\section{Determination of the heat production of the cells}

The diathermic isoperibol reaction calorimeter consisted of a demountable Dewar vessel equipped with a stirrer, a heater, a thermistor $(1 \mathrm{k} \Omega)$ and an inlet for introducing a second component. This system was immersed in a very stable thermostat (TRONAC) with a temperature stability well within $1 \mathrm{mK}$ (Loesberg et al., 1982). The temperature was measured with a Wheatstone bridge which was fed with a constant current supply. The limit of detection in the temperature measurement was $1.8 \times 10^{-4} \mathrm{~K}$, this corresponded to a heat effect of $1.5 \times 10^{-5} \mathrm{~J}$. A heater was used for internal calibration and for speeding up the reaching of the equilibration temperature. A constant current supply stable within $0.01 \%$ was used for the heat input. These constant current supplies were homemade and described elsewhere (Schaake et al., 1979). The inbalance of the bridge was measured at regular time intervals by a microcomputer system (Apple 11) which was equipped with a digital voltmeter (Leeds \& Northrup 4.5 digits) and a timer card. The apparatus was calibrated by determining the heat of a solution of $\mathrm{KCl}$; the result for 10 measurements being $17346 \mathrm{~J} \mathrm{~mol}^{-1}$ with a standard deviation of $34 \mathrm{~J} \mathrm{~mol}^{-1}$. Measurements of the heat production were performed as described before for Reuber H35 cells (Loesberg $e t$ al., 1982) and the heat production was derived from the derivative of the temperature against time $(\mathrm{d} T / \mathrm{d} t)$.

\section{DNA and protein synthesis}

Procedures for cell counting. DNA and protein synthesis measurements were described before (van Wijk et al., 1972).

\section{Chemicals}

All tissue components were purchased from Flow Chemical (U.S.A.). $\left[{ }^{3} \mathrm{H}\right]$ Thymidine and $\left[{ }^{3} \mathrm{H}\right]$ leucine were from the Radiochemical Centre (Amersham. U.K.). Nocodazole (methyl[5-(2-thienyl-carbonyl) $1 \mathrm{H}$-benzimidazol-2-yl]carbamate) was a product from Aldrich Chemical Co. Inc.

\section{RESULTS}

Heat production of synchronized Neuro- $2 A$ cells isolated by mitotic shake-off

Treatment of an asynchronous culture of Neuro-2A cells with Nocodazole arrested these cells in metaphase. Based on the cell-cycle data of this cell line (de
Laat et al., 1980; Boonstra et al., 1980; van Zoelen et al., 1981) including an average cell-cycle duration of $9 \mathrm{~h}$, the theoretical yield of mitotic cells can be calculated for various periods of Nocodazole treatment. Experimentally, treatment for more than $7 \mathrm{~h}$ did not result in a higher yield of mitotic cells. By cinematography it was found that cells escaped from the mitotic round-cell configuration after longer times of Nocodazole treatment. Thus, in our procedure, mitotic cells from a culture treated for $7 \mathrm{~h}$, with Nocodazole at a final concentration of $0.15 \mu \mathrm{g} \mathrm{m}^{-1}$, were then specifically detached by shaking (yield more than $95 \%$ mitotic cells) and incubated in suspension culture.

We used the continuous incubation of $\left[{ }^{3} \mathrm{H}\right]$ thymidine to monitor the DNA synthetic phase of these cells. Figure 1A shows the period of DNA synthesis from 2.5 to $7 \mathrm{~h}$, resembling the Neuro-2A cell cycle in monolayer culture. The thermogram of a synchronized Neuro-2A cell population in suspension is shown in Fig. 1B. After a small decrease the cellular heat production increased slightly during the early $G 1$

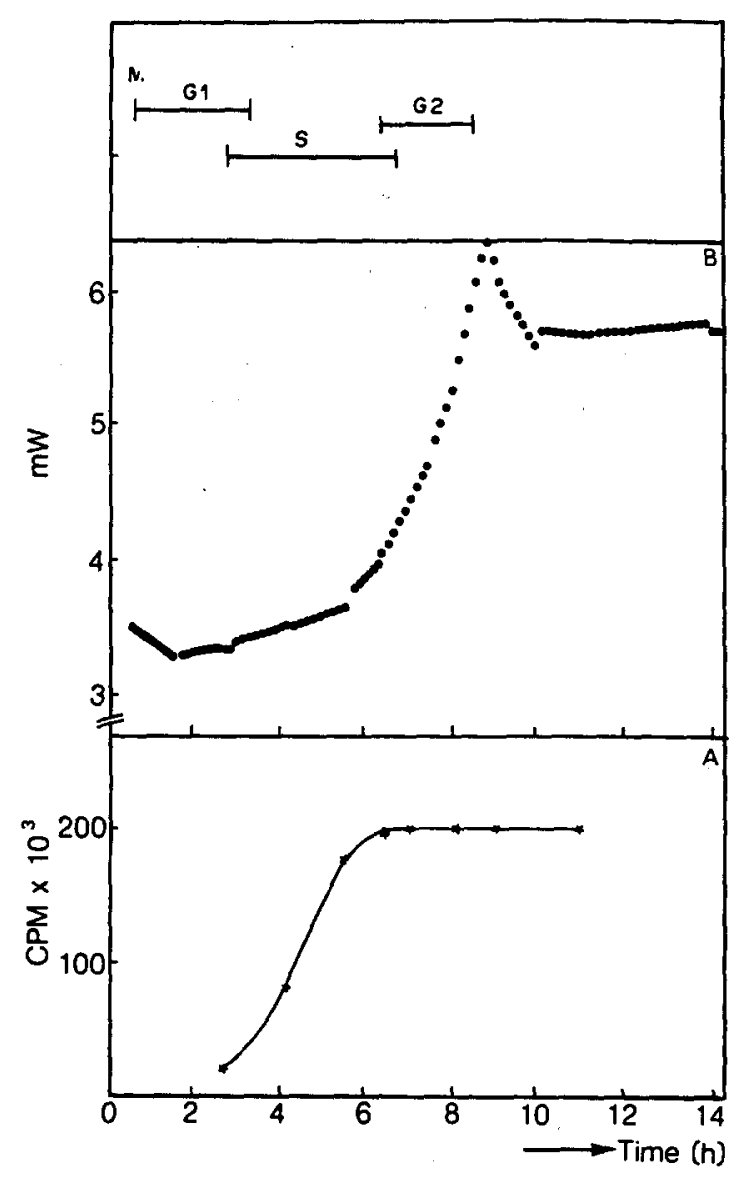

Fig. 1. A. DNA-synthesis of Nocodazole-synchronized murine $C 1200$ neuroblastoma cells, clone Neuro-2A in suspension culture. Neuroblastoma cells, synchronized by Nocodazole in metaphases, collected by mitotic shake-off, were introduced in suspension culture at $37^{\circ} \mathrm{C}$ under stirring conditions. $\left[{ }^{3} \mathrm{H}\right]$ Thymidine $(100 \mu \mathrm{Ci})$ was added to the medium and at various times samples were taken (continuous label). B. Heat production of $3 \times 10^{7}$ neuroblastoma cells synchronized in metaphase by Nocodazole (in $\mathrm{mW}$ ). 


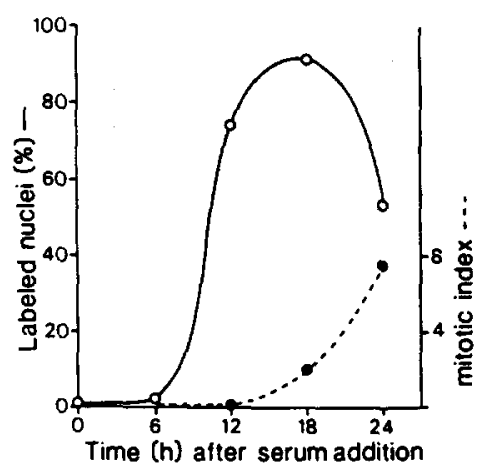

Fig. 2. Initiation of DNA synthesis and mitosis after serum addition. Reuber H35 rat hepatoma cells were synchronized by a 72-h incubation in serum-free medium. After serum readdition $\left[{ }^{3} \mathrm{H}\right]$ thymidine incorporation at various times was determined by 30 -min $\left[{ }^{3} \mathrm{H}\right]$ thymidine pulse labelling (O). Percent mitotic cells ( )

period, but remained relatively constant. Heat production started to increase slowly when cells were in S-phase. It increased very rapidly in cells at the end of their S-phase, reaching double of its value at $2 \mathrm{~h}$ after the end of the DNA synthetic phase, i.e. during initial mitosis. Then a slight decrease was observed again. The accuracy of the measured values for the total heat production (in $\mathrm{mW}$ ) was calculated to be in the order of $2-5 \%$. Assuming that the uncertainty in the equilibrium temperature may amount to $50 \mu \mathrm{V}$ and that the error in the constant $\mathrm{L}$ is $10 \%$ or $4 \times 10^{-6} \mathrm{~S}^{-1}$. This would lead to an error in the heat production of $0.16 \mathrm{~mW}$. The heat production of the cell masses used is in the order of $3-10 \mathrm{~mW}$, so this error being about $5-2 \%$.

\section{Heat production of synchronized Reuber $\mathrm{H} 35$ cells}

Proliferation of Reuber H35 hepatoma cells requires attachment to a plastic or glass substratum and the presence of serum in the growth medium. When the medium is depleted for serum the multiplication of cells in a monolayer culture ceased and the population becomes arrested in the early Gl-phase of the cell cycle. Such serum-depleted monolayer cultures remain viable and growth can be reinitiated by adding back fresh serum. Figure 2 shows the cell cycle. After a delay there is an increase in the rate of

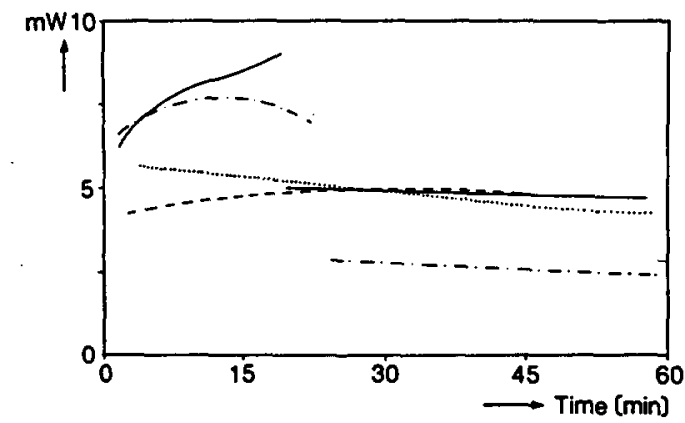

Fig. 3. Total heat production of $2 \times 10^{8}$ synchronized H35 cells (in $\mathrm{mW}$ ) at $0(---), 7(\cdots), 14(-\cdot)$ ) and $24 \mathrm{~h}(-)$ after serum readdition. $\left[{ }^{3} \mathrm{H}\right]$ thymidine incorporation in DNA. A more detailed analysis of variations in some molecular events of the Reuber $\mathrm{H} 35$ hepatoma cell cycle has been reported previously (van Wijk et al., 1979a, van Wijk et al., 1979b).

At four different stages $(0,7,14$ and $24 \mathrm{~h})$ after reinitiation of growth by serum addition, suspension cultures were prepared. Heat production of the suspension cultures were measured microcalorimetrically at $37^{\circ} \mathrm{C}$. A total of 12 heat-production measurements were performed in three different experimental sessions. The results being fairly reproducible. A representative example of the obtained thermograms is given in Fig. 3. The heat production of hepatoma cells as determined immediately after transfer to the suspension culture in the microcalorimetry vessel showed low values for cells at Gl-phase times of 0 and $7 \mathrm{~h}$ after serum readdition. Increased initial values were observed for cells at later times of their cell cycle. The average values for the first $15 \mathrm{~min}$ of incubation in suspension were $22.5,28,36.5$ and $37 \mathrm{pW} /$ cell at 0,7 , 14 and $24 \mathrm{~h}$ after serum readdition. Moreover the thermograms showed a remarkable difference between the heat evolution in a suspension of H3S-cells derived from GI-phase monolayer cultures (early and late) and that of cells in later phases of their cell cycle (Fig. 3 ). In GI-cells heat production was relatively continuous during the measurement. In contrast cells in later phases showed a sudden decrease in heat production after an initial maximum. The absence of the transiently increased heat production in G1-phase cells did not favour the explanation that our method induced these heat-production overshoot effects as a consequence of the temperature step-down and step-up procedure. Instead, cells in the late part of their cell cycle had a selective heat-producing process that is stopped soon after their incubation in suspension culture. This alteration in cell conformation might play a crucial role in chromatin replication (Wittelsberger \& Folkman, 1981).

We decided to study this chromatin replication and used for this purpose an asynchronous Reuber H35 cell culture which showed a similar decrease in heat production after some time in suspension culture (Fig. 4). Figure 5 shows that after the introduction of the Reuber H35 cells into suspension, DNA synthesis is

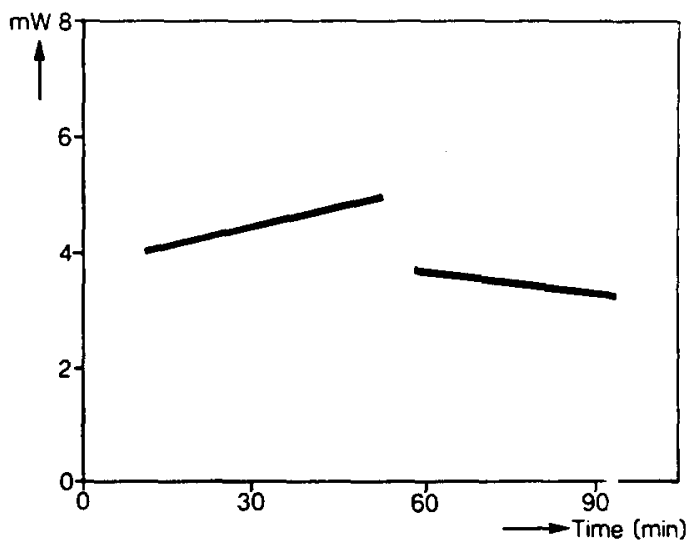

Fig. 4. The heat production (in $\mathrm{mW}$ ) of a-synchronous H35-cells in suspension culture. 


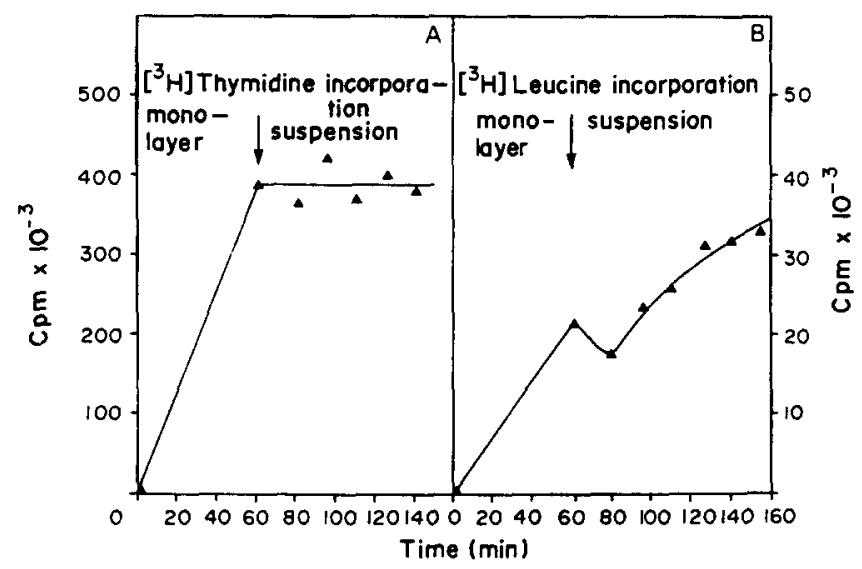

Fig. 5. Rate of DNA (4A) and protein (4B) synthesis in asynchronous H35-cells in monolayer and after transfer into suspension culture. Label was added at zero time, $1 \mathrm{~h}$ later the medium was removed and stored. cells washed. trypsinized and resuspended in the original medium containing the respective label. At various times during continuous incubation at $37^{\circ} \mathrm{C}$ the amount of the incorporated label was determined.

inhibited nearly immediately (Fig. 5A). In contrast to the inhibition of DNA synthesis, the rate of protein synthesis is hardly affected by the transition from a monolayer to a suspension culture (Fig. 5B).

\section{DISCUSSION}

In this study two cell types have been used which differ in the regulation of their chromosome cycle including DNA replication, condensation and cell division. The rat hepatoma cell-line Reuber H35 was not capable of any initiation of the chromosome cycle in suspension culture. In monolayer culture, cells were strongly attached to the surface and initiation of the chromosome cycle was completely serum dependent. A mitotic shake-off procedure for this hepatoma cell line did not result in any selective detachment. Two reasons were found. At first, cells were only in a round cell shape for a short period of time, independent of the concentration of mitotic inhibitor, and then flattened again. The second reason was that even in its rounded shape the intercellular contacts completely inhibited selective cellular detachment.

The Neuro-2A cell showed a different behaviour. This cell line was capable of initiating and performing its chromosome cycle in suspension culture. This cell type was less sensitive towards serum and was difficult to synchronize by serum deprivation. However, this cell type appeared to be sensitive for the mitotic inhibitor Nocodazole, a compound which had been used in several other cell-cycle studies. In any case, by the used procedures large populations of synchronized cells of both cell types could be obtained to study thermogenesis at several stages during cell-cycle progression. One of the major conclusions arising from the thermographic data was that the heat production per cell type was strongly different. For the neuroblastoma cells it changed during the cell cycle between 60 and $120 \mathrm{pW} /$ cell, while for Reuber $\mathrm{H} 35$ cells it changed between 20 and $40 \mathrm{pW} /$ cell. Nevertheless the values could be compared with those obtained from some other mammalian cell types (Schaarschmidt \& Reichert, 1981).

A second major conclusion is that heat production during the progression of the cell through its cell cycle was not linear. Especially cells in the later part of their cell cycle of their chromosome cycle showed an increased heat production. Theoretically this could be explained in two ways:

(1) At the end of the cell cycle there is a sudden change in energy production leading to corresponding increased heat losses.

(2) During the cell cycle there is only a gradual increase in energy production but the experimentallyfound changes in the loss of heat reflect inversely the enthalpy of the system.

In view of the latter possibility it might be speculated that the heat loss was related to the condensation cycle of the chromatin. It is known that a decondensed state occurs during S-phase, while maximal condensation occurs in mitosis (Sawicki, 1979; Beall, 1979). This will be further explored in our laboratory.

Acknowledgement-This work was financially supported by the Netherlands Organization for the Advancement of Pure Research (Z.W.O.).

\section{REFERENCES}

BEALL P. T. (1979) Applications of cell biology to an understanding of biological water. In Cell Associated Water (Edited by Drost-Hansen W. \& ClegG J.), pp. 271-291. Academic Press. New York.

Boonstra J., Mummery C. L., Tertoolex L. G. J., SaAg P. T. VAN DER \& LAAT S. W. DE (1981) Cation transport and growth regulation in neuroblastoma cells. Modulations of $\mathrm{K}^{+}$transport and electrical membrane properties during the cell cycle. J. Cell Physiol. 107, 75-83.

Brabander M. J. DE, Veire R. M. L. VAN DE, AerTs F. E. M., Borgers M. \& JANSSEN P. A. J. (1976) The effects of methyl[5-(2-thienylcarbonyl)-1 H-benzimidanol-2-yl] carbamate, (R 17934; NSC 238159), a new synthetic antitumoral drug interfering with microtubules, on mammalian cells cultured in vitro. Cancer Res. 36, 905-916. 
Kemp R. D. (1980) Microcalorimetric studies on tissue cells in vitro. In Biological Microcalorimetry (Edited by Beezer A. E.), pp. 113-325. Academic Press. New York.

LaAT S. W. DE, SAaG P. T. VAn der, Elson E. L. \& SCHLESSINGER J. (1980) Lateral diffusion of membrane lipids and protein during the cell cycle of neuroblastoma cells. Proc. natn. Acad. Sci. U.S.A. 77, 1526-1528.

Loesberg C., Miltenburg J. C. van \& Wijk R. van (1982) Heat production of Reuber $\mathrm{H} 35$ rat hepatoma cells under normo- and hyperthermia conditions. J. therm. Biol. 7, 87-90.

SAwICKI W. (1979) Chromatin pattern in-situ dependence upon cell cycle, pre-implantation development and cellular aging in vitro. In Chromatin Structure and Function (Edited by NiCOLINI C.), pp. 667-681. Plenum Press, New York.

SchaAke R. C. F., Offringa J. C. A.. Berg G. J. K. van DeR \& Miltenburg J. C. van (1979) Phase transition in solids, studied by adiabatic calorimetry-1. Design and test of an automatic adiabatic calorimeter. Recl Trav. chim. Pays-Bas Belg. 98, 409-412.

SchaARschmidt B. \& Reichert U. (1981) Heat evolution by human skin fibroblasts in monolayer culture. Expl Cell Res. 131, 480-483.

Schamhart D. H. J., Van de Poll K. W. \& Wijk R. van (1979) Comparative studies of glucose metabolism in HTC, RLC, MH C and Reuber H35 rat hepatoma cells Cancer Res. 39, 1051-1055.

SPINK C. H. (1980) Analytical calorimetry in biochemical and clinical applications. C.R.C. crit. Rev. analyt. Chem. 9, 1-54.

Terasima T. \& Tolmach L. J. (1963) Growth and nucleic acid synthesis in synchroneously dividing populations of HeLa cells. Expl Cell Res. 30. 344-362.

WIJK R. VAN. WICKS W. D. \& Clay K. (1972) Effects of derivatives of cyclic $3^{\prime}, 5^{\prime}$-adenosine monophosphate on the growth, morphology, and the gene expression of hepatoma cells in culture. Cancer Res. 32, 1905-1911.

Wisk R. VAN. Zoutewelle G. \& POll K. W. vaN dE (1979a) Regulation of initiation of DNA synthesis in relation to mitosis in cultures hepatoma cells. Cell Biol. int. Rep. 3, 447-452.

Wijk R. van. Zoutewelle G., Defer N., Tichosicky L. \& KRUH J. (1979b) Variations in some molecular events during the early phase of the Reuber $\mathrm{H} 35$ hepatoma cell cycle-l. Glucocorticoid induction of tyrosine aminotransferase. Biochimie 61, 711-717.

WitTelsberger S. \& FolKman J. (1981) Cell conformation and growth control. In Cell Growth (Edited by Nicolini C.). pp. 575-585. Plenum Press, New York.

Zoelen E. J, J. van, SaAg P. T. van der, LaAt S. W. de (1981) Family tree analysis of a transformed cell line and the transition probability model for the cell cycle. Expl Cell Res. 131, 395-406.

Key Word Index-Heat production; hepatoma cells; neuroblastoma cells; microcalorimetry; cell cycle. 